\title{
Insights into the mechanism and catalysis of peptide thioe- ster synthesis by alkylselenols provide a new tool for chemi- cal protein synthesis
}

\author{
Florent Kerdraon, ${ }^{1}$ Gemma Bogard, ${ }^{1}$ Benoît Snella, ${ }^{1}$ Hervé Drobecq,,${ }^{1}$ Muriel Pichavant, ${ }^{1}$ Vangelis Agouri- \\ das,,$^{1,2^{*}}$ Oleg Melnyk ${ }^{*}$
}

Univ. Lille, CNRS, Inserm, CHU Lille, Institut Pasteur de Lille, U1019 - UMR 9017 - CIIL - Center for Infection and Immunity of Lille, F-59000 Lille, France;

2 Centrale Lille, F-59000 Lille, France ;

* $\quad$ Correspondence: oleg.melnyk@ibl.cnrs.fr, vangelis.agouridas@ibl.cnrs.fr

\begin{abstract}
While thiol-based catalysts are widely employed for chemical protein synthesis relying on peptide thioester chemistry, this is less true for selenol-based catalysts whose development is in its infancy. In this study, we compared different selenols derived from the selenocysteamine scaffold for their capacity to promote thiol-thioester exchanges in water at mildly acidic $\mathrm{pH}$ and the production of peptide thioesters from bis(2-sulfanylethyl)amido (SEA) peptides. The usefulness of a selected selenol compound is illustrated by the total synthesis of a biologically active human chemotactic protein, which plays an important role in innate and adaptive immunity.
\end{abstract}

Keywords: Peptide thioester, alkylselenol, catalysis, chemical protein synthesis

\section{Introduction}

Chemical protein synthesis is now established as an alternative mode of production of tailored proteins for use in diverse fields of research, primarily biological and medicinal research [1]. Thioester chemistry is central to the field of chemical protein synthesis by the frequent application of the native chemical ligation (NCL [2-6], Figure 1A) and methods derived thereof to the chemoselective formation of peptide junctions to cysteine in water using unprotected peptide segments as reactants [7].

Besides the assembly of the protein itself and the acceleration of peptide bond formation, [8-12] one limitation of chemical protein synthesis using NCL is the production of the peptide thioester segments [13]. Therefore, facilitating the access to the peptide thioesters using Fmoc-SPPS has been intensively pursued, especially during the last decade, and the progress made in this area explains in part the rapid increase in the number of protein targets assembled since 2010 [1,7]. One corpus of methods that has contributed to the progress of chemical protein synthesis exploits the capacity of $N$-(2-mercaptoethyl)amides, i.e. $N, S$-acyl shift systems [14-31], to rearrange into thioesters in aqueous media. Several of these systems have been validated by the synthesis of challenging proteins [3239].

One popular mode of use of N,S-acyl shift systems is the production of alkylthioesters by exchanging the N-(2mercaptoethyl)amine unit by a thiol used in excess, i.e. R'SH in Figure 1B. Such exchange reactions are equilibrated, the equilibrium being displaced toward the thioester form at acidic $\mathrm{pH}$ probably due to the masking of the departing $N$-(2-mercaptoethyl)amine by protonation [40]. Detailed mechanistic studies performed on the bis(2-sulfanylethyl)amido (SEA) system established that in such conditions the thiol-thioester exchanges are rate limiting. This is because thiol-thioester exchanges proceed preferably through thiolate species [41], while the attacking thiol $\mathrm{R}^{\prime} \mathrm{SH}$ in the process shown in Figure 1B is mostly in its neutral form at the acidic $\mathrm{pH}$ used for the exchange reaction, typically $\mathrm{pH} 4$ [42]. These mechanistic findings led to the conclusion that the production of peptide thioesters from SEA peptides might be facilitated by catalyzing the thiol/thioester exchange step shown in Figure 1B. Indeed, efficient catalysis could be achieved by using diselenol catalyst $8 \mathbf{a}$ obtained by reduction of diselenide $7 \mathbf{a}\left(R^{\prime \prime}=\right.$ alkyl group, Figure 1D), which in practice was found to be superior to other classical thiol or selenol additives for promoting the production of peptide thioesters from SEA peptides at $\mathrm{pH} 4$. The design of catalyst $8 \mathbf{a}$ has been inspired by the observation that the simpler diselenol $\mathbf{8 b}\left(R^{\prime \prime}=H\right.$, Figure 1D) was able to catalyze the SEA/thiol exchange 
reaction, albeit with byproduct formation due to the presence in $\mathbf{8 b}$ of a nucleophilic secondary amine, hence the introduction of a blocking alkyl group on the nitrogen.

A)

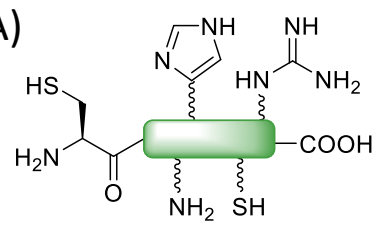
Cysteinyl peptide 1<smiles>NC(=O)C(N)(c1ccc(O)cc1)C(O)C(O)C(=O)O</smiles>

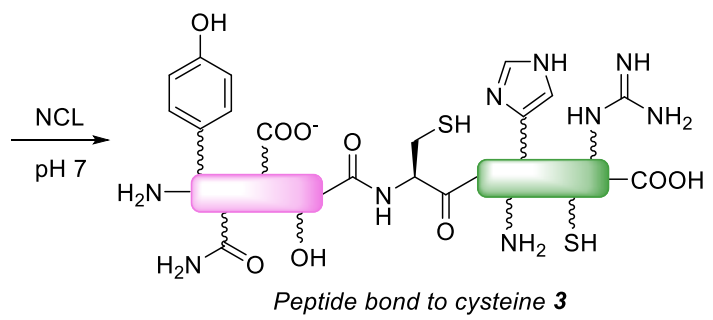

B)

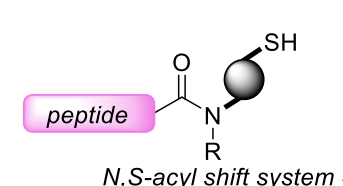

${ }_{4}^{N, \text { S-acyl shift }}$
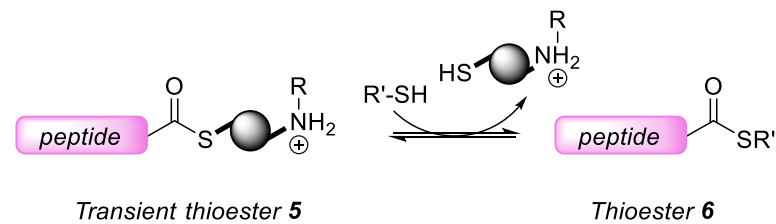

N,S-acyl shift system

Transient thioester 5

Thioester 6

C)

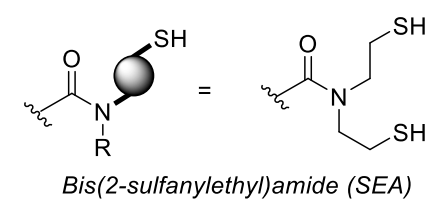

D)

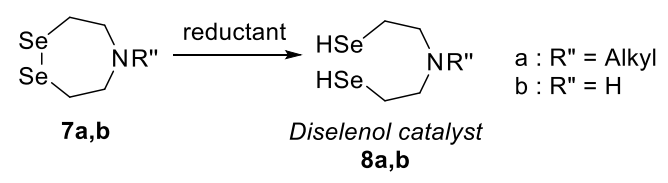

Figure 1. A) Principle of the native chemical ligation (NCL). B) N,S-acyl shift amide systems rearrange into thioesters in aqueous solution and can be used for producing stable thioesters by exchange with a thiol. C) The bis(2sulfanylethyl)amide (SEA) system. D) Selenol catalysts reported by Cargoët et al. [42].

The diverse kinetic data collected so far support that the catalysis of the SEA/thiol exchange reaction by selenols proceeds as shown in Figure $2[40,42]$. According to this mechanism, the SEA peptide 9 undergoes a spontaneous $\mathrm{N}, \mathrm{S}$-acyl shift to produce the transient SEA thioester $\mathbf{1 0}$. The latter reacts with the selenol catalyst probably through selenoate species to produce selenoester 12, which then undergoes an exchange reaction with the thiol additive used in excess. The catalytic potency of selenols stems from their low $\mathrm{pK}_{\mathrm{a}}$ compared to thiols, which ensures that a significant fraction of the selenol is in the form of a nucleophilic selenoate at the working acidic $\mathrm{pH}$ for the reaction, and also from the strong acylating properties of selenoesters of type 12.[9,12]

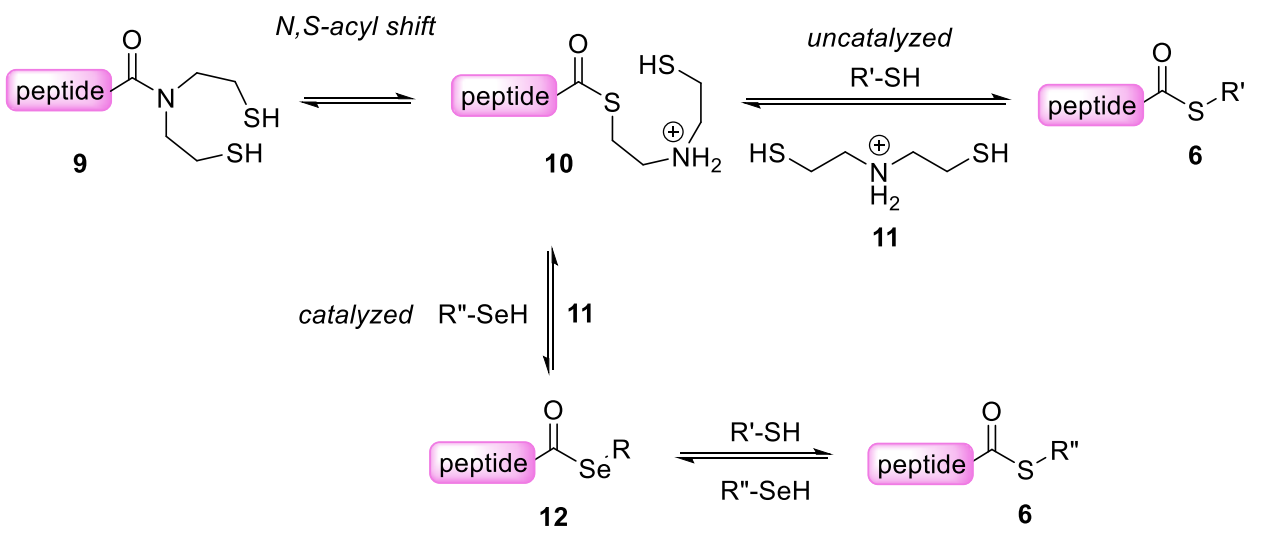

Figure 2. Mechanism of the SEA/thiol exchange catalysis by selenols.

The ease of synthesis, the catalytic potency and the water solubility are certainly key points to consider in the design of catalysts acting on unprotected peptide segments. Diselenol catalysts of type 8a are efficient and water soluble 
but their synthesis is complex and low yielding. This latter limitation prompted us to search for novel selenol catalysts whose production would be easier. Evolving catalyst 8a structure into easier to make selenol catalysts while maintaining similar catalytic potencies is not obvious. This is because the importance of the bis selenol and tertiary amine functionalities in the catalysis by $8 \mathbf{a}$ remains unknown. In addition, the consequences of changing catalyst structure on selenol nucleophilicity and $\mathrm{pK}_{\mathrm{a}}$ are hard to predict.

In this work, we evaluated the interest of selenol compounds $\mathbf{1 3}$ and $\mathbf{1 4}$ for catalyzing the SEA/thiol exchange process (Figure 3). These compounds, which share the 2-(selanylethyl)amino motif with original catalyst 8a, have been studied in the past as analogs of choline [43-45]. They have the advantage of being easily produced in multigram quantities from cheap starting materials. Detailed kinetic studies showed the capacity of selenol $\mathbf{1 3}$ to act as a substitute of diselenol 8a for the synthesis of peptide thioesters. Its usefulness is illustrated by the first chemical synthesis of a biologically active $9 \mathrm{kDa}$ granulysin protein, an antibacterial human protein secreted by cytotoxic cells in response to various infectious agents [46-48].<smiles>CN(C)CC[SeH]</smiles>

13

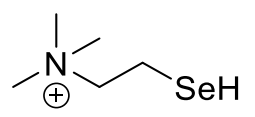

14

Figure 3. Selenol catalysts studied in this work.

\section{Results and discussion}

\subsection{Catalyst synthesis}

Catalysts 13 and 14 were produced as their corresponding diselenides, i.e. diselenides 17 and 18 respectively, starting from 2-chloro- $\mathrm{N}, \mathrm{N}$-dimethylethylamine hydrochloride according to known procedures [45,49]. Briefly, 2chloro- $\mathrm{N}, \mathrm{N}$-dimethylethylamine was neutralized with potassium carbonate and then reacted with potassium selenocyanate to produce $N, N$-dimethyl-2-selenocyanatoethan-1-amine 16, which upon treatment with sodium hydroxide afforded diselenide 17. Diselenide 17 was easily alkylated with methyl iodide to produce diselenide $\mathbf{1 8 .}$

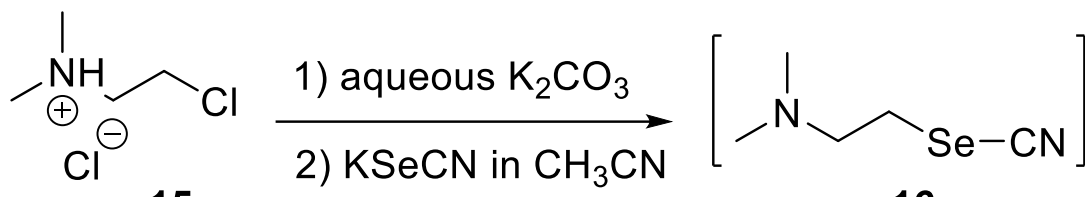

15

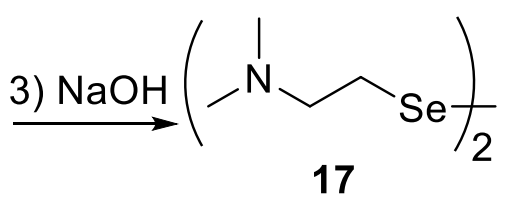

(88\% from 15)
16

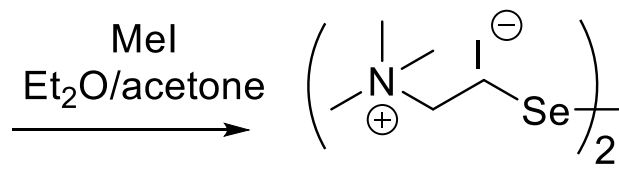

$18(40 \%)$

Scheme 1. Synthesis of catalysts $\mathbf{1 3}$ and $\mathbf{1 4}$ in the form of their diselenides $\mathbf{1 7}$ and 18, respectively.

\subsection{Kinetic studies}

The SEA/thiol exchange reaction used for studying the potency of the different catalysts is shown in Scheme 2. The water soluble tris(2-carboxyethyl)phosphine (TCEP) enables an in situ reduction of the cyclic SEA off disulfide 19 and of the diselenide catalyst $\mathbf{1 7}$ or $\mathbf{1 8}$. The thiol additive used in this reaction is 3-mercaptopropionic acid (MPA), which is a classical thiol used for preparing peptide thioesters. 

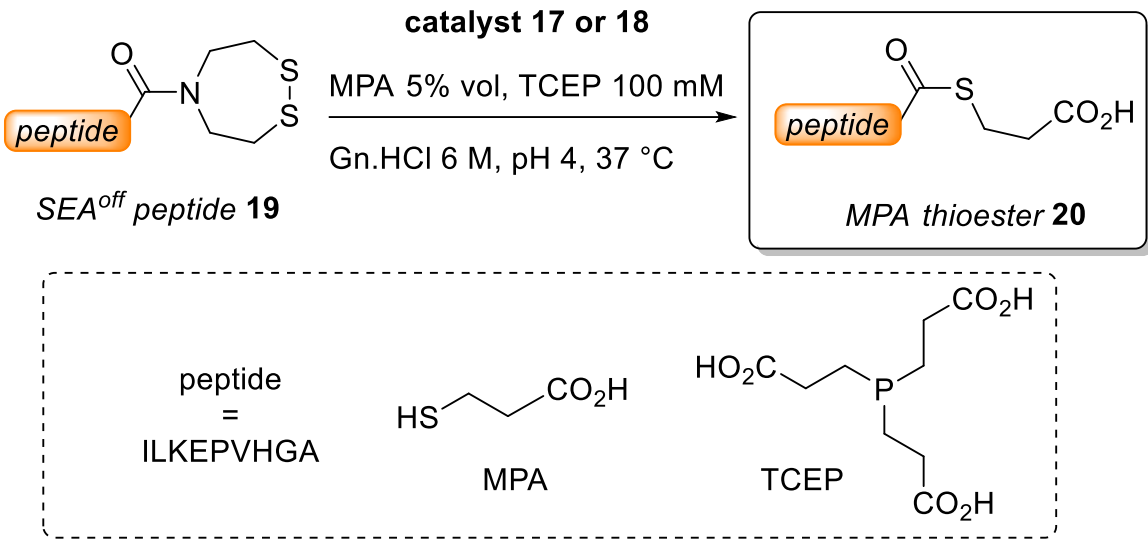

Scheme 2 . The SEA/thiol exchange reaction investigated by kinetic studies.

The exchange reactions were monitored by HPLC (Figure 4A). The kinetic data were fitted to extract the apparent second order rate constants (Figure 4B). As suggested by the experimental data shown in Figure 4B, the rate constants obtained for $\mathbf{1 7}$ and $7 \mathrm{a}$ plateau above $25 \mathrm{mM}$ at the same value. However, examination of Figure $4 \mathrm{~B}$ or of Table 1, which gives the half-reaction times for the different experiments, shows that the potencies of catalysts $\mathbf{1 7}$ and $7 \mathbf{a}$ are not the same below $25 \mathrm{mM}$ with the SEA/thiol exchange reaction proceeding faster with catalyst $7 \mathbf{a}$. The difference is particularly stricking by looking at the data obtained at low catalyst concentration (compare for example blue circles and triangles for $\mathbf{1 7}$ and $7 \mathrm{a}$ respectively used at $3.13 \mathrm{mM}$ concentration). We can conclude at this point that diselenide catalyst $7 \mathbf{a}$ can be substituted by diselenide 17 with the condition of being used at a minimal concentration of $25 \mathrm{mM}$, under which conditions the highest rate for the SEA/thiol exchange reaction can be achieved.

The ability of diselenide 18 to accelerate the SEA/MPA exchange reaction was also assessed according to the same conditions. Whether at a concentration of $100 \mathrm{mM}, 50 \mathrm{mM}$ or $25 \mathrm{mM}$, catalyst 18 was found to be significantly less potent than diselenides $\mathbf{7 a}$ or $\mathbf{1 7}$ (Table 1). We noticed the formation of a red solid in the reaction mixture after a few hours at the highest concentration tested $(100 \mathrm{mM})$, probably elemental selenium (see Supplementary Information, Figure S16). This observation strongly suggests that catalyst 18 decomposes throughout the course of the reaction. We also noticed an increase of the $\mathrm{pH}$ of the reaction mixture, a phenomenon that was not observed with the other diselenides. Since previous studies established that the SEA/thioester ratio at equilibrium increases with $\mathrm{pH}[40,42]$, the $\mathrm{pH}$ drift observed in these experiments might explain in part the diminished conversion observed with catalyst 18. Taken together, the lower conversion and rates observed with catalyst $\mathbf{1 8}$ preclude its use as an interesting alternative to $7 \mathbf{a}$ for the production of peptide thioesters from SEA peptides. 
Table 1. Catalysis of SEA-thiol exchange using diselenides $7 \mathbf{a}, 17$ or 18 a,

\begin{tabular}{cccccc}
\hline Entry & $\begin{array}{c}\text { Catalyst conc. } \\
(\mathbf{m M})\end{array}$ & \multicolumn{3}{c}{ Catalyst } \\
& & $\mathbf{t a}_{\mathbf{1} / \mathbf{2}}(\mathbf{h})$ & $\mathbf{1 7}$ & $\mathbf{1 8}^{\mathrm{d}}$ \\
\hline 1 & 100 & 2.04 & 1.73 & 2.51 \\
2 & 50 & 2.03 & 2.08 & 2.87 \\
3 & 25 & 1.95 & 2.22 & 3.60 \\
4 & 12.5 & 2.35 & 3.21 & nd \\
5 & 6.25 & 3.00 & 4.60 & nd \\
6 & 3.13 & 3.35 & 5.87 & nd
\end{tabular}

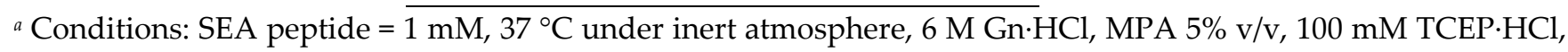
$\mathrm{pH}$ 4.0. ${ }^{\mathrm{b}}$ The half-reaction time $\left(\mathrm{t}^{1} / 2\right)$ for the uncatalyzed reaction is $7.28 \mathrm{~h}$ [42]. ${ }^{\mathrm{c}}$ Data from ref [42]. ${ }^{\mathrm{d}}$ Measured $\mathrm{pH}$ at equilibrium: $\mathrm{pH} 4.45$ at $100 \mathrm{mM} \mathrm{18,} \mathrm{pH} 4.19$ at $50 \mathrm{mM}$ 18, pH 4.14 at $25 \mathrm{mM} 18$.

Another stricking observation that has been done during the HPLC-MS monitoring of the exchange process catalysed by diselenide 18 was the formation of the peptide selenoester derived from selenocholine in substantial amounts (Figure 4C). In contrast, the amount of selenoester formed during the SEA/thiol exchange catalysed by diselenides $7 \mathrm{a}$ or $\mathbf{1 7}$ was below HPLC-MS detection limits. The persistence of the selenoester derived from 18 in the reaction mixture suggests that the quaternarization of the basic nitrogen significantly alters the reactivity of the carbonyl group nearby. This observation is reminiscent of the work of Mautner and coworkers, who noticed that the hydrolysis of 2-dimethylaminoethyl selenobenzoate proceeded significantly faster at $\mathrm{pH} 7$ than hydrolysis of benzoylselenocholine. The authors proposed that the formation of an intramolecular hydrogen bond between the protonated secondary amine and the selenoester carbonyl oxygen might promote the nucleophilic attack of the hydroxide ion on the selenoester carbonyl [44]. Such an intramolecular activation of the selenoester group by the protonated amine as illustrated in Figure 5 might contribute to the catalytic potency of diselenides $\mathbf{7 a}$ and $\mathbf{1 7 .}$ 
A)

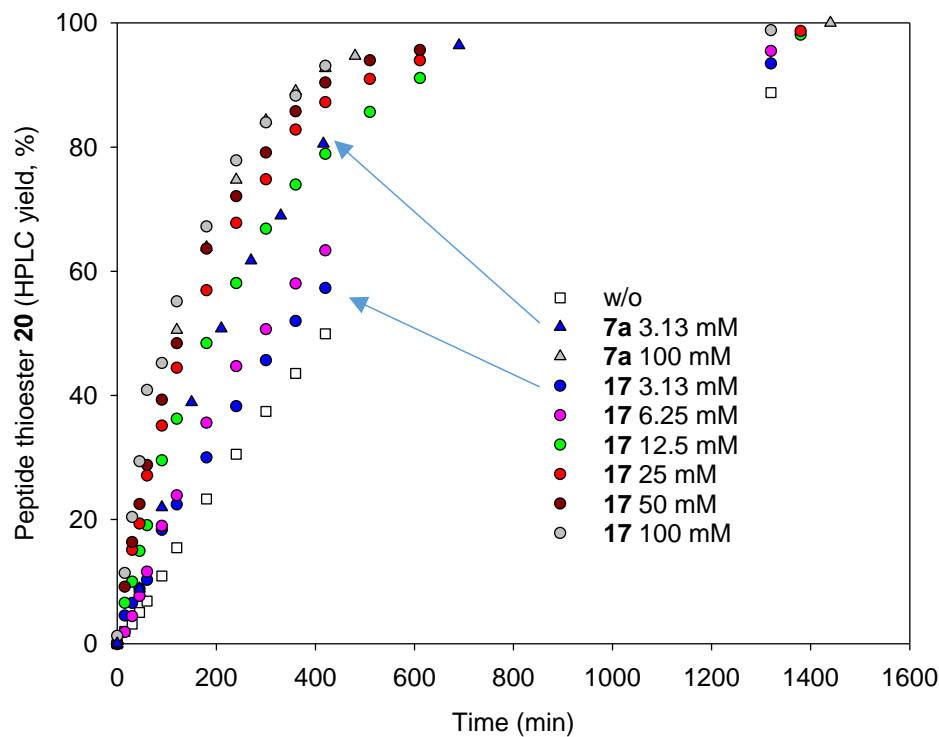

B)
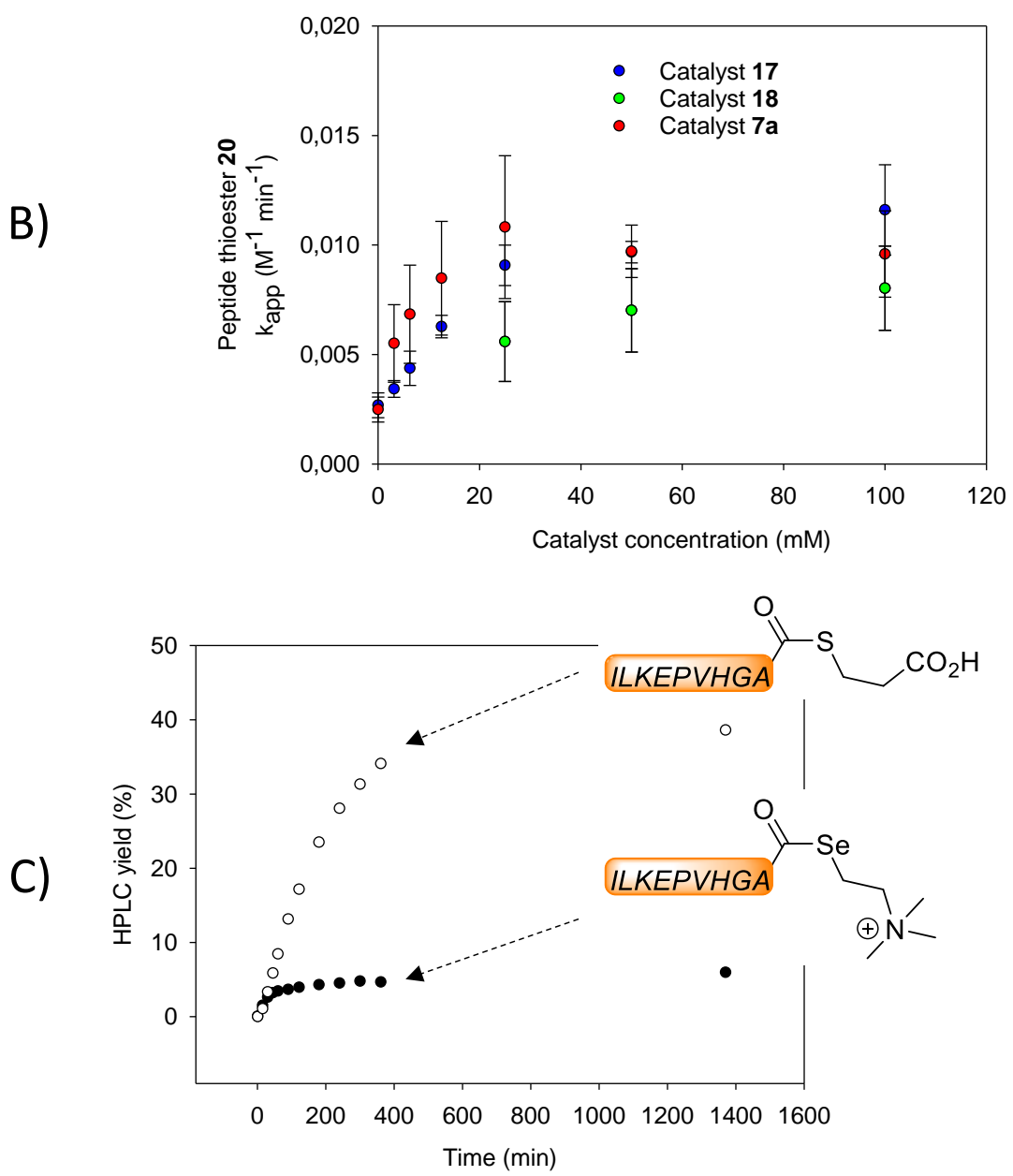

Figure 4. Study of the SEA/thiol exchange reaction catalysed by diselenides $7 \mathbf{a}$ or 17 . Conditions: SEA peptide $=1$ $\mathrm{mM}, 37^{\circ} \mathrm{C}$ under inert atmosphere, $6 \mathrm{M} \mathrm{Gn} \cdot \mathrm{HCl}$, MPA 5\% v/v, $100 \mathrm{mM}$ TCEP.HCl, pH 4.0. A) Experimental data as obtained by HPLC monitoring. B) Apparent second-order rate constants obtained by fitting experimental data. The error bars correspond to the standard error of the fit. C) Kinetic profile in the presence of catalyst $\mathbf{1 8}$ used at $100 \mathrm{mM}$. 


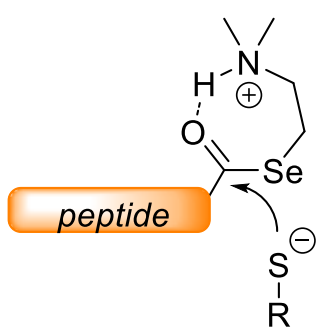

Figure 5. The presence of a protonated amine nearby the peptide carbonyl might promote the attack of thiol nucleophiles.

2.3 Total chemical synthesis of $9 \mathrm{kDa}$ granulysin

To illustrate the usefulness of the new deselenide catalyst 17, we undertook the total chemical synthesis of $9 \mathrm{kDa}$ granulysin (9-GN, Figure 6A). 9-GN is a human cytotoxic and proinflammatory protein that belongs to the NKlysin family of proteins [48,50,51]. The protein is stabilized by two disulfide bonds. 9-GN protein is secreted by specialized cells from the immune system in response to infection by various agents such as bacteria, parasites, fungi and viruses. Designing an efficient and modular synthetic approach toward 9-GN can facilitate the development of novel antibacterial proteins of potential therapeutic interest.

The synthetic strategy that was followed for accessing the linear 9-GN polypeptide (9-GN-1) is described in Figure 6B. 9-GN-1 polypeptide was assembled from three peptide segments using NCL, which are highlighted by orange (N-terminal), blue (middle) and green (C-terminal) colors in Figure 6. The preceding residue of all the cysteines present in 9-GN sequence are $\beta$-branched amino acid residues, meaning that regardless of the AA-Cys junctions chosen for 9-GN assembly, the formation of difficult peptidic junctions will have to be dealt with. The assembly was done in the C-to- $\mathrm{N}$ direction and therefore required the protection of the N-terminal cysteine residue of the middle segment to avoid its cyclization or oligomerization during the first ligation step. The acetoacetyl (AcA) group was chosen for this purpose due to its ease of installation and removal [32-34,52].

The preparation of the middle thioester segment 21 in blue in Figure 6B proved to be challenging. First the classical Fmoc SPPS of the SEA peptide precursor resulted in low yields due to difficult couplings after Arg94. This problem was solved by introducing Ala92 and Thr93 as a pseudoproline dipeptide unit, i.e. Fmoc-Ala-Thr( $(\mathrm{Me}, \mathrm{Me}) \operatorname{Pro}-$ $\mathrm{OH}$ (Figure 7) [53]. The second issue was the sluggish SEA/MPA exchange process enabling the installation of the thioester group, due to the presence of a sterically demanding valine residue at the C-terminus. Diselenide catalyst 17 proved to be particularly useful in this case. Interestingly, the protection of the N-terminal cysteine residue using methyl-S-(acetoacetyl)-thioglycolate (AcA-MTG) in the presence of 4-mercaptophenylacetic acid (MPAA) and the diselenide-catalyzed SEA/MPA exchange reaction could be performed in one-pot with a $\mathrm{pH}$ change in between, thereby saving one intermediate purification step. 
A)

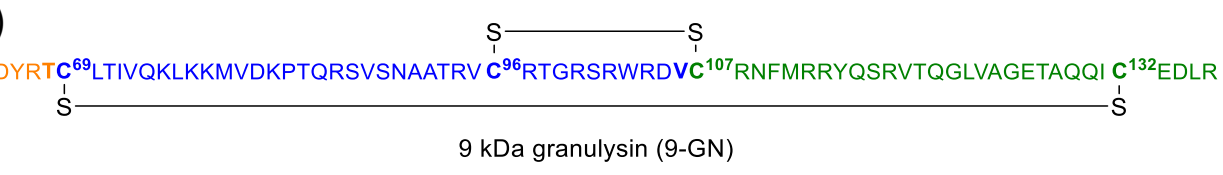

B)

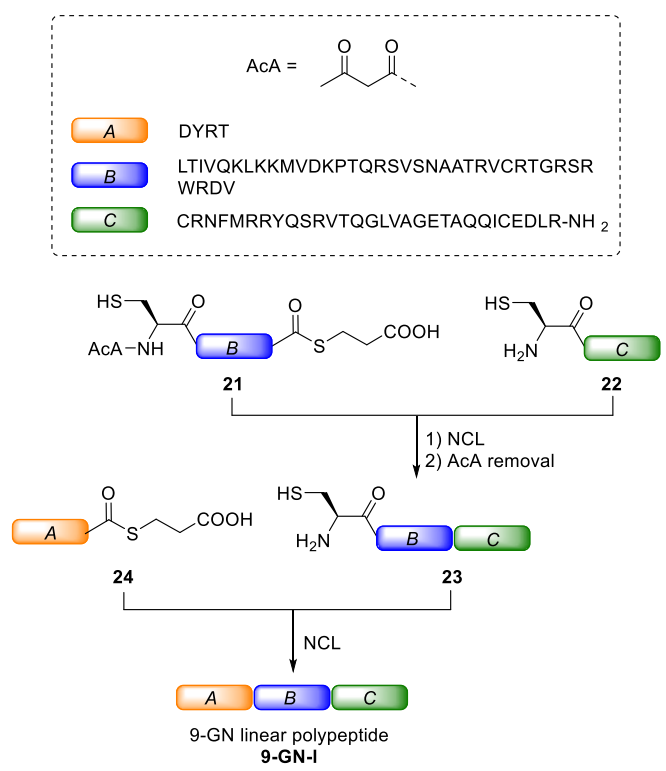

Figure 6. A) Primary structure of 9-GN and pattern of disulfide bonds. B) General strategy used for assembling the linear 9-GN polypeptide (9-GN-1).

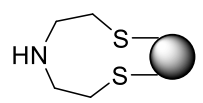

25

1) Fmoc-SPPS

Coupling of Fmoc-Ala-Thr( $\Psi(\mathrm{Me}, \mathrm{Me})$ Pro-

$\mathrm{OH}$ for $\mathrm{A}^{92}-\mathrm{T}^{93}$

2) $T F A ; 3) I_{2}$

C(StBu)LTIVQKLKKMVDKPTQRSVSNAA ${ }^{92} T^{93}$ RVC(StBu)RTGRSRWRDV

26 (17\% from 22$)$
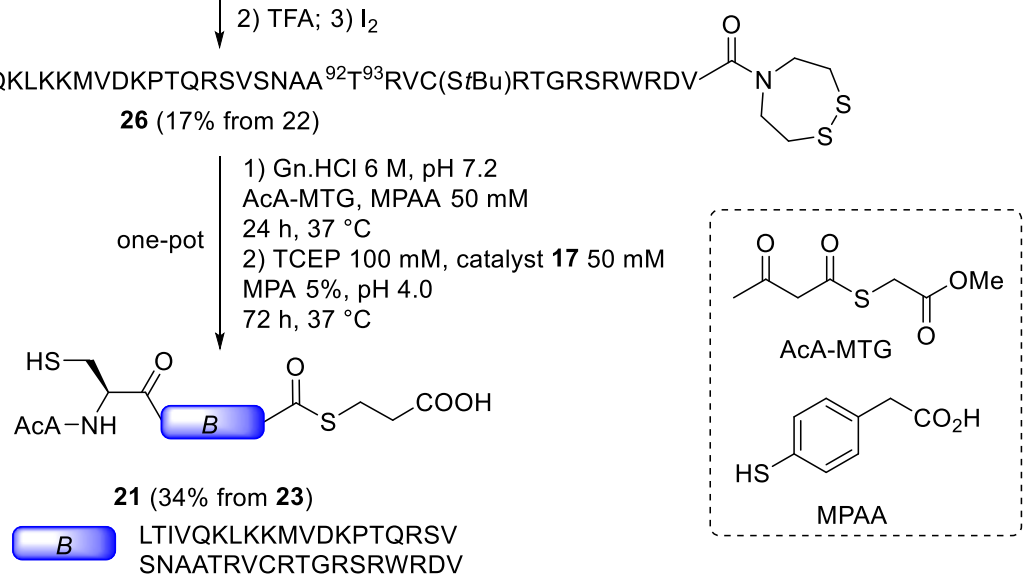

Figure 7. Synthesis of the middle thioester segment 21 by alkyl diselenide-catalyzed SEA/MPA exchange. 
The successful synthesis of thioester segment 21 set the stage for the assembly of the linear 9-GN-1 polypeptide (Figure 8). The ligation of middle 21 and right 22 segments was followed by the removal of the AcA group in onepot by adding hydroxylamine hydrochloride to the reaction mixture and adjusting the $\mathrm{pH}$ to mildly acidic values. The second ligation step with peptide thioester 24 provided the full length 9-GN-1 polypeptide which was purified by HPLC.

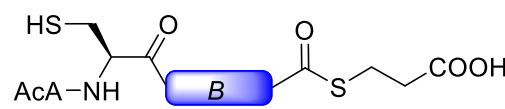

21

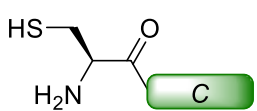

22

1) $\mathrm{Gn} . \mathrm{HCl} 6 \mathrm{M}, \mathrm{pH} 7.2$

MPAA $200 \mathrm{mM}, 24 \mathrm{~h}, 37^{\circ} \mathrm{C}$

2) $\mathrm{H}_{2} \mathrm{NOH} . \mathrm{HCl}, \mathrm{TCEP}$

$4 \mathrm{~h} \mathrm{pH} 5.5-3.0,37^{\circ} \mathrm{C}$

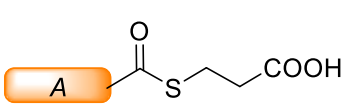

24

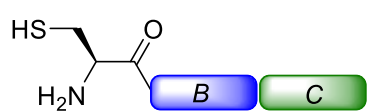

$23(56 \%)$

Gn.HCl $6 \mathrm{M}, \mathrm{pH} 7.2$

MPAA $200 \mathrm{mM}, 24 \mathrm{~h}, 37^{\circ} \mathrm{C}$

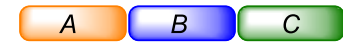

9-GN linear polypeptide

9-GN-I (78\%)

PBS/glycerol 9/1 v/v

Folding $\mathrm{Gn} \cdot \mathrm{HCl} 2 \mathrm{M}$

GSH $1 \mathrm{mM} / \mathrm{GSSG} 0.2 \mathrm{mM}$ $20{ }^{\circ} \mathrm{C}, 8$ days

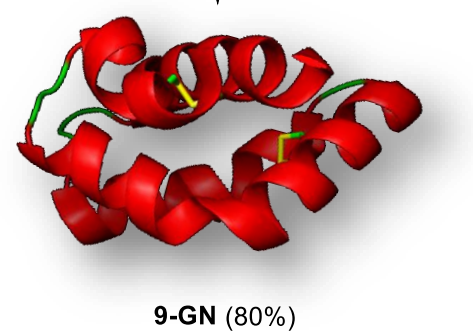

Figure 8. Total synthesis of 9-GN (the structure of 9-GN shown in this figure was prepared using Pymol and pdb entry 1L9L[54]).

The folding step was performed at $20^{\circ} \mathrm{C}$ in a phosphate buffered saline/glycerol $9 / 1$ mixture in the presence of glutathione $(1 \mathrm{mM})$ /glutathione disulfide $(0.2 \mathrm{mM})$ redox system and guanidinium hydrochloride as a solubilizing additive. The use of guanidine hydrochloride during this step was mandatory to enable the solubilisation of the linear 9-GN-1 polypeptide. The formation of the native pattern of disulfide bonds as shown in Figure 6A has been demonstrated by identifying the peptides produced upon trypsin digestion under non-reducing conditions by mass spectrometry (see Supplementary Information). The UPLC-MS analysis of 9-GN shown in Figure 9 highlights the quality of the protein obtained by the designed synthetic route. 


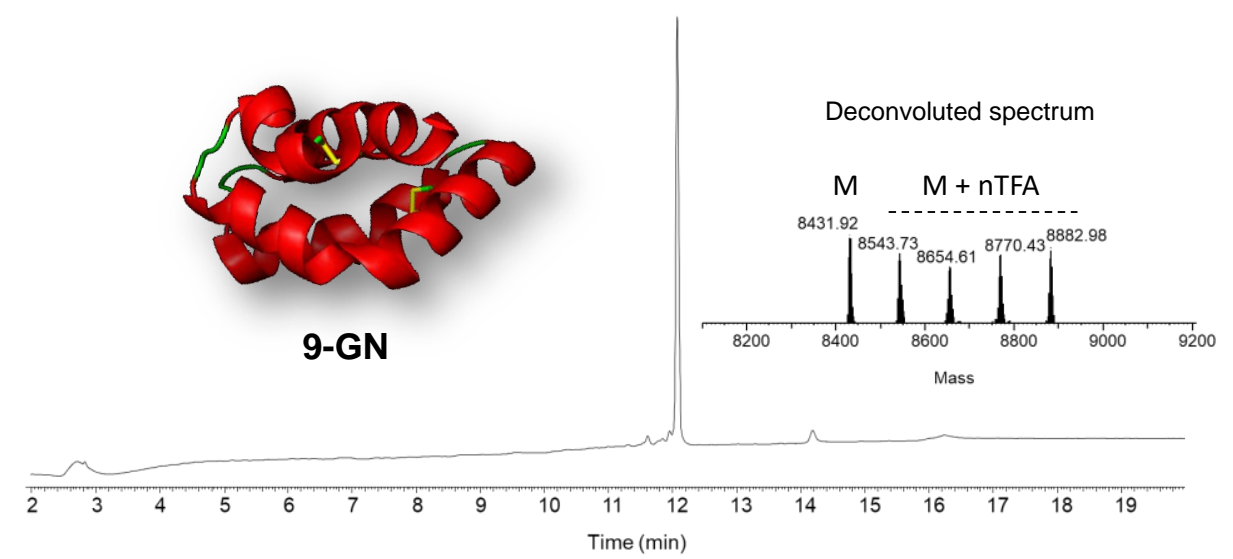

Figure 9. UPLC-MS analysis of synthetic 9-GN. UV-detection at $215 \mathrm{~nm}$. M (average mass) calcd. 8431.79, obs. 8431.9. 9-GN is a cationic protein that shows several TFA adducts in its deconvoluted MS spectrum. The structure of 9-GN shown in this figure was prepared using PyMol and pdb entry 1L9L [54].

\subsection{Biological activity of synthetic 9-GN}

The successful synthesis and folding of 9-GN set the stage for examining its biological activity. One hallmark of 9GN is its capacity to induce the migration of immune cells to the site of infection. Typically, 9-GN is a chemoattractant for monocytes in the low nanomolar range in a transwell migration assay performed in Boyden micro chambers.

In such an assay, monocytes are placed on the upper layer of a cell permeable membrane inserted in a multi-well plate, which separates the cells from the solution containing the chemoattractant. After incubation (1 hour), the cells that have migrated through the membrane are stained and counted. In such an assay, the synthetic 9-GN protein displayed a strong migration index in the 1-100 nM range as expected from literature data (Figure 9), showing the biological functionality of the protein obtained by chemical synthesis [51].

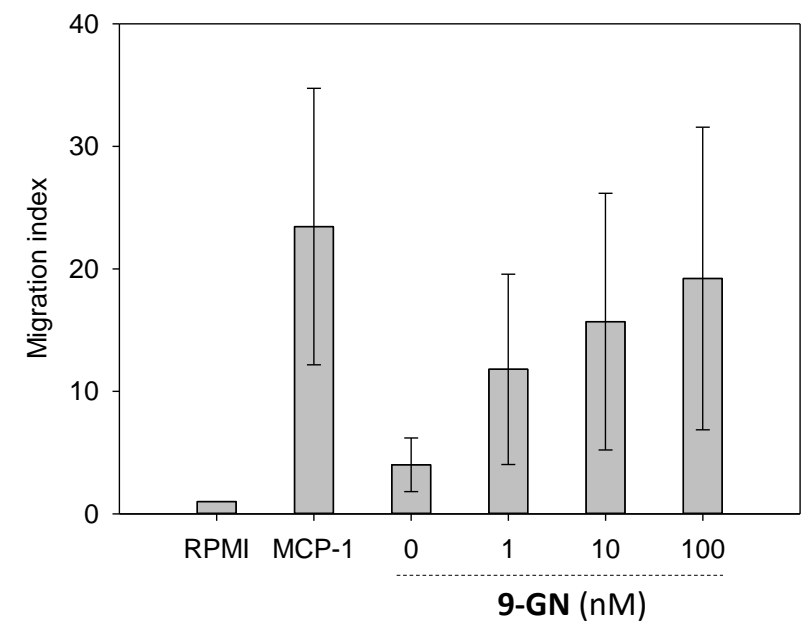

Figure 9. Monocyte migration assay in Boyden micro chambers. The data are expressed relative to the cell migration observed in the Roswell Park Memorial Institute medium (RPMI 1640) supplemented with $0.1 \%$ fetal calf serum. Monocyte chemotactic protein-1 (MCP-1, also called CCL2, $23 \mathrm{nM}$ ) was used as a positive control. The data for 0 $\mathrm{nM}$ of $9-\mathrm{GN}$ were obtained using the protein dialysis buffer (PBS containing $10 \%$ in vol of glycerol). The bars correspond to the mean for six donors, from whom monocytes were isolated. The error bar correspond to the standard error of the mean. The data for each donor can be found in the Supplementary Information.

\section{Materials and Methods}

3.1 Synthesis of diselenide 17 
To a solution of potassium carbonate $(11.5 \mathrm{~g}, 0.083 \mathrm{~mol})$ in water $(30 \mathrm{~mL})$, was added 2-chloroethyl- $N, N$-dimethylamine hydrochloride $(6.0 \mathrm{~g}, 0.042 \mathrm{~mol})$. The resulting mixture was stirred at room temperature for $10 \mathrm{~min}$. The resulting crude mixture was extracted 3 times with $30 \mathrm{~mL}$ of $\mathrm{Et}_{2} \mathrm{O}$, dried over $\mathrm{MgSO}_{4}$ and concentrated under reduced pressure. $1.0 \mathrm{~g}$ of the resulting pale yellow oil $(9.3 \mathrm{mmol})$ was diluted in $90 \mathrm{~mL}$ of acetonitrile and potassium selenocyanate $(1.47 \mathrm{~g}, 10.2 \mathrm{mmol})$ was added portionwise. The resulting solution was stirred at room temperature for $16 \mathrm{~h}$. Et $2 \mathrm{O}(100 \mathrm{~mL})$ was added to the reaction mixture which was then filtered through a pad of celite. The filtrate was evaporated in vaccuo and then redissolved in $120 \mathrm{~mL}$ of absolute ethanol. Aqueous sodium hydroxide $(60 \mathrm{~mL}, 1 \mathrm{M})$ was slowly added under stirring and the reaction mixture was stirred $3 \mathrm{~h}$ at room temperature. The resulting mixture was concentrated in vacuo to remove the maximum of ethanol and extracted $\mathrm{Et}_{2} \mathrm{O}(3 \times$ $30 \mathrm{~mL}$ ). The organic layers were combined, dried over $\mathrm{MgSO}_{4}$ and concentrated under reduced pressure to afford diselenide 17 as a yellow oil ( $1.24 \mathrm{~g}, 4.09 \mathrm{mmol}, 88 \%)$.

${ }^{1} \mathrm{H}$ NMR $\left(300 \mathrm{MHz}, \mathrm{CDCl}_{3}\right) \delta(\mathrm{ppm}) 3.10-2.96(\mathrm{~m}, 4 \mathrm{H}), 2.68-2.55(\mathrm{~m}, 4 \mathrm{H}), 2.25(\mathrm{~s}, 12 \mathrm{H})$ (see Figure $\left.\mathrm{S} 12\right)$.

${ }^{13} \mathrm{C} \mathrm{NMR}\left(75 \mathrm{MHz}, \mathrm{CDCl}_{3}\right.$ ) $\delta$ (ppm) 60.32, 45.20, 28.20 (see Figure $\mathrm{S} 13$ ).

MALDI-TOF Matrix 2,5-dihydrobenzoic acid, positive detection mode, calcd. for $[\mathrm{M}+\mathrm{H}]^{+}$(exact mass): 305.00 , found: 304.92.

\subsection{Synthesis of 9-GN}

\section{Step 1. Synthesis of peptide thioester 21}

To a solution of $\mathrm{Gn} \cdot \mathrm{HCl}(1.1 \mathrm{~g})$ in $0.1 \mathrm{M} \mathrm{pH} 7.4$ phosphate buffer $(1.2 \mathrm{~mL})$ was added MPAA $(17 \mathrm{mg}, 50 \mathrm{mM})$. SEA off peptide 26 (15 mg, $2.6 \mu \mathrm{mol}, 1.0$ equiv) and AcA-MTG $(77 \mu \mathrm{L}$ of a $0.10 \mathrm{M}$ solution in ACN, $7.7 \mu \mathrm{mol}, 3.0$ equiv) were then successively dissolved in the MPAA solution $(1.3 \mathrm{~mL})$ and the $\mathrm{pH}$ of the mixture was adjusted to 7.2 by addition of $6 \mathrm{M} \mathrm{NaOH}$. The mixture was stirred at $37^{\circ} \mathrm{C}$ for $8 \mathrm{~h}$. 3.0 additional equivalents of AcA-MTG were added and the mixture was stirred an additional $16 \mathrm{~h}$ at $37^{\circ} \mathrm{C}$ under nitrogen atmosphere. Completion of the reaction was ascertained by UPLC-MS analysis.

After protection of the $\mathrm{N}$-terminal Cys residue $(24 \mathrm{~h})$, the subsequent SEA/MPA exchange reaction was carried out in one-pot. TCEP. $\mathrm{HCl}(34 \mathrm{mg}, 0.10 \mathrm{M})$, diselenide catalyst $17(20 \mathrm{mg}, 50 \mathrm{mM})$ and MPA $(65 \mu \mathrm{L}, 5 \%$-vol $)$ were added to the previous mixture. The $\mathrm{pH}$ was adjusted to 4.0 by addition of $6 \mathrm{M} \mathrm{NaOH}$ and the reaction mixture was stirred at $37^{\circ} \mathrm{C}$ for $72 \mathrm{~h}$. After completion of the reaction, the mixture was diluted in $10 \mathrm{~mL}$ of water containing $0.1 \%$ TFA. The crude was purified by HPLC (eluent $\mathrm{A}=$ water containing $0.1 \%$ TFA, eluent $\mathrm{B}=$ acetonitrile in water $4 / 1 \mathrm{v} / \mathrm{v}$ containing $0.1 \%$ TFA, $50^{\circ} \mathrm{C}$, detection at $215 \mathrm{~nm}, 6 \mathrm{~mL} \mathrm{~min}^{-1}, 0-37 \%$ eluent $\mathrm{B}$ in $15 \mathrm{~min}$, then $37-57 \%$ eluent $\mathrm{B}$ in 60 min, C18XBridge column) to give peptide thioester 21 as a white solid after lyophilization ( $5.09 \mathrm{mg}$, 34\%).

Peptide 21 was analyzed by UPLC-MS (see Figure S 17) and MALDI-TOF mass spectrometry (see Figure S 18).

ESI (positive detection mode, see Figure S 17): calcd. for [M] (average): 4561.40, found: 4561.79.

MALDI-TOF (positive detection mode, matrix 2,5-dihydrobenzoic acid, see Figure S 18): calcd. for $[\mathrm{M}+\mathrm{H}]^{+}$(average): 4562.40 , found: 4562.87 .

\section{Step 2. Synthesis of peptide amide 23}

To a solution of $\mathrm{Gn} \cdot \mathrm{HCl}(0.57 \mathrm{~g})$ in $0.1 \mathrm{M}, \mathrm{pH} 7.4$ phosphate buffer $(0.60 \mathrm{~mL})$ was added MPAA $(34 \mathrm{mg}, 0.20 \mathrm{mmol})$ and the $\mathrm{pH}$ of the mixture was adjusted to 7.2 by addition of $6 \mathrm{M} \mathrm{NaOH}$. Peptide 21 ( $3.5 \mathrm{mg}, 0.61 \mu \mathrm{mol}, 1.0$ equiv) and peptide $22(2.8 \mathrm{mg}, 0.67 \mu \mathrm{mol}, 1.1$ equiv) were then successively dissolved in the MPAA solution $(0.12 \mathrm{~mL})$ and the $\mathrm{pH}$ of the mixture was adjusted to 7.2 by addition of $6 \mathrm{M} \mathrm{NaOH}$. The mixture was stirred at $37^{\circ} \mathrm{C}$ for $24 \mathrm{~h}$ under nitrogen atmosphere. Completion of the reaction was insured by UPLC-MS analysis.

After completion of the NCL ligation ( $24 \mathrm{~h}$ ), the AcA protecting group was removed by reaction with $\mathrm{NH}_{2} \mathrm{OH}$. The reaction mixture was first acidified to $\mathrm{pH} 3.0$ with $6 \mathrm{M} \mathrm{HCl}$ and extracted 3 times with $1.0 \mathrm{~mL}$ of Et $\mathrm{t}_{2} \mathrm{O}$ to remove MPAA. A $0.5 \mathrm{M}$ solution of $\mathrm{NH}_{2} \mathrm{OH} \cdot \mathrm{HCl}$ in $\mathrm{H}_{2} \mathrm{O}(26 \mu \mathrm{L}, 13 \mu \mathrm{mol}, 20$ equiv $)$ was then added and the $\mathrm{pH}$ was adjusted to 5.5. After $4 \mathrm{~h}$ stirring at $37^{\circ} \mathrm{C}$, $\mathrm{pH}$ was adjusted to 3.0 with $0.25 \mathrm{~g} \mathrm{~mL}^{-1}$ aqueous solution of TCEP.HCl. The crude was further diluted in $4.0 \mathrm{~mL}$ of water containing $0.25 \%$ TFA and purified by HPLC (eluent $\mathrm{A}=$ water containing $0.25 \%$ TFA, eluent $\mathrm{B}=$ acetonitrile in water $4 / 1 \mathrm{v} / \mathrm{v}$ containing $0.25 \% \mathrm{TFA}, 50^{\circ} \mathrm{C}$, detection at $215 \mathrm{~nm}, 6 \mathrm{~mL}$ $\mathrm{min}^{-1}, 0-40 \%$ eluent B in $10 \mathrm{~min}$, then $40-50 \%$ eluent B in $45 \mathrm{~min}, \mathrm{C} 18 X$ Bridge column) to afford peptide 23 as a white solid after lyophilization ( $3.49 \mathrm{mg}, 56 \%$ ).

Peptide 23 was analyzed by UPLC-MS (see Figure S 19) and MALDI-TOF mass spectrometry (see Figure S 20). ESI (positive detection mode, see Figure S 19): calcd. for [M] (average): 7899.22, found: 7899.94.

MALDI-TOF (positive detection mode, matrix 2,5-dihydrobenzoic acid, see Figure S 20): calcd. for [M+H]+ (average): 7900.22 , found: 7901.49 . 
Step 3. Synthesis of $\mathbf{9 - G N - 1}$

To a solution of $\mathrm{Gn} \cdot \mathrm{HCl}(0.57 \mathrm{~g})$ in $0.1 \mathrm{M} \mathrm{pH} 7.4$ phosphate buffer $(0.60 \mathrm{~mL})$ was added MPAA $(34 \mathrm{mg}, 0.20 \mathrm{mmol})$ and the $\mathrm{pH}$ of the mixture was adjusted to 7.7 by addition of $6 \mathrm{M} \mathrm{NaOH}$. Peptide 23 ( $3.5 \mathrm{mg}, 0.36 \mu \mathrm{mol}, 1.0$ equiv) and peptide thioester $24(0.38 \mathrm{mg}, 0.36 \mu \mathrm{mol}, 1.0$ equiv) were then successively dissolved in the MPAA solution (91 $\mu \mathrm{L}$ ) The mixture was stirred at $37^{\circ} \mathrm{C}$ for $24 \mathrm{~h}$ under nitrogen atmosphere. Completion of the reaction was insured by UPLC-MS analysis.

After completion of the NCL ligation $(24 \mathrm{~h}), \mathrm{TCEP} \cdot \mathrm{HCl}(5.2 \mathrm{mg}, 18 \mu \mathrm{mol})$ was added to the reaction medium to reduce any mixed disulfide formed during ligation. The resulting mixture was diluted in $3.0 \mathrm{~mL}$ of water containing $0.1 \%$ TFA. The crude was purified by HPLC (eluent $\mathrm{A}=$ water containing $0.1 \%$ TFA, eluent $\mathrm{B}=$ acetonitrile in water $4 / 1 \mathrm{v} / \mathrm{v}$ containing $0.1 \% \mathrm{TFA}, 50^{\circ} \mathrm{C}$, detection at $215 \mathrm{~nm}, 6 \mathrm{~mL} \mathrm{~min}{ }^{-1}, 0-38 \%$ eluent $\mathrm{B}$ in $10 \mathrm{~min}$, then $38-58 \%$ eluent B in $60 \mathrm{~min}, \mathrm{C} 18 \mathrm{XBridge}$ column) to give $\mathbf{9 - G N - 1}$ as a white solid after lyophilization (2.92 $\mathrm{mg}$, $78 \%$ ).

Peptide 9-GN-1 was analyzed by UPLC-MS (see Figure S 21) and MALDI-TOF mass spectrometry (see Figure S 22). ESI (positive detection mode, see Figure S 21): calcd. for [M] (average): 8435.79, found: 8435.45.

MALDI-TOF (positive detection mode, matrix 2,5-dihydrobenzoic acid, see Figure $\mathrm{S} 22$ ): calcd. for $[\mathrm{M}+\mathrm{H}]^{+}$(average): 8436.79 , found: 8436.65 .

\subsection{Folding}

The linear polypeptide 9-GN-1 $(0.558 \mathrm{mg}, 0.054 \mu \mathrm{mol})$ was dissolved in PBS containing $10 \%$ by vol of glycerol, 2 $\mathrm{M}$ of $\mathrm{Gn} \cdot \mathrm{HCl}, 1 \mathrm{mM}$ reduced glutathione, $0.2 \mathrm{mM}$ oxidized glutathione $(1 \mathrm{~mL} / \mathrm{mg}$ final peptide concentration). The reaction mixture was let $1 \mathrm{~h}$ at $0{ }^{\circ} \mathrm{C}$ and then 8 days at $20^{\circ} \mathrm{C}$.

The protein was dialyzed twice (respectively $2 \mathrm{~h}$ and $24 \mathrm{~h}$ ) at $20^{\circ} \mathrm{C}$ against $200 \mathrm{~mL}$ PBS containing $10 \%$ in vol of glycerol. $0.71 \mathrm{~mL}$ of the dialyzed solution were recovered and the concentration of the folded protein was determined using UV quantification at $280 \mathrm{~nm}(60.7 \mu \mathrm{M}, 0.043 \mu \mathrm{mol}, 80 \%)$

Folded protein 9-GN was analyzed by UPLC-MS (see Figure $S$ 23).

Experimental determination of the disulfide bridge pattern was achieved by trypsin digestion of 9-GN and identification of the resulting fragments by mass spectrometry using non-reducing conditions. Fragments obtained by digestion with trypsin permitted the direct assignment of Cys69-Cys132 and Cys96-Cys107 disulfide bonds (see Figure S 25 in the Supplementary Information).

\subsection{Chimiotaxis assay}

Blood monocytes were purified from six donors by positive selection over a MACS column using anti-CD14-conjugated microbeads (Miltenyi Biotec) as previously described [55].

Monocyte migration ( $5 \times 10^{4}$ cells/well in $50 \mu \mathrm{L}$ of RPMI 1640 medium with $0.1 \%$ FCS) was performed in a 48 -well Boyden microchamber (Neuroprobe) through a standard $5-\mu \mathrm{m}$ pore filter (Neuroprobe), at $37^{\circ} \mathrm{C}$ for 1 hour. Migration was evaluated in response to synthetic granulysin (1 to $100 \mathrm{nM}$ in RPMI 1640 medium containing $0.1 \%$ FCS), CCL2 used as positive control ( $200 \mathrm{ng} / \mathrm{mL}, 23.1 \mathrm{nM}$, R\&D Systems), and medium alone used as negative control. The filter was stained using Diff-Quik reagent. Migrated cells were counted on the lower side of the filter in three randomly selected high power fields (magnification $\times 100$ ). Each assay was performed in triplicate. Results are expressed as the difference between mean numbers of cells per high power fields minus the negative control (medium alone).

\section{Conclusions}

We conducted detailed kinetic studies of the catalysis of the bis(2-sulfanylethyl)amido (SEA)/thiol exchange process by selenols derived from the selenocysteamine. These data provide important clues regarding the role played by the basic amino group of the selenocysteamine scaffold in catalysis and how to evolve the catalyst to achieve useful catalytic potencies while minimizing synthetic cost. Catalysis by bis $(\mathrm{N}, \mathrm{N}$-dimethylaminoethyl)diselenide proved particularly useful and involves presumably an intramolecular general acid catalysis by the proton of the dimethylammonium group. Bis( $\mathrm{N}, \mathrm{N}$-dimethylaminoethyl)diselenide can be easily produced in multigram scale from cheap starting materials. Its usefulness is illustrated by the chemical synthesis of a biologically actice $9 \mathrm{kDa}$ granulysin.

Supplementary Materials: The detailed experimental procedures and characterization data for all compounds are provided in a separate pdf file. 
Author Contributions: F.K.: catalyst synthesis and kinetic measurements, 9-GN total synthesis, writing-review; G.B.: chemotactic assays; B.S.: catalyst synthesis and kinetic measurements; H.D.: Proteomic experiments; M.P.: chemotactic assays, writingreview; V.A.: conceptualization, project administration, supervision, methodology, kinetic modelizations, writing - review \& editing; O.M.: conceptualization, project administration, supervision, methodology, writing - review \& editing. All authors have read and agreed to the published version of the manuscript.

Funding: This work was supported by the CNRS, the University of Lille, the Pasteur Institute of Lille and by ANR grant ANR18-CE44-0010.

Institutional Review Board Statement: Not applicable.

Informed Consent Statement: Not applicable.

Data Availability Statement: Not applicable.

Conflicts of Interest: The authors declare no conflict of interest.

\section{References}

1. Agouridas, V.; El Mahdi, O.; Melnyk, O. Chemical Protein Synthesis in Medicinal Chemistry. J. Med. Chem. 2020, 63, 1514015152.

2. Dawson, P.E.; Muir, T.W.; Clark-Lewis, I.; Kent, S.B.H. Synthesis of Proteins by Native Chemical Ligation. Science 1994, 266, 776-779.

3. Raibaut, L.; Ollivier, N.; Melnyk, O. Sequential Native Peptide Ligation Strategies for Total Chemical Protein Synthesis. Chem. Soc. Rev. 2012, 41, 7001-7015.

4. Conibear, A.C.; Watson, E.E.; Payne, R.J.; Becker, C.F.W. Native Chemical Ligation in Protein Synthesis and Semi-Synthesis. Chem. Soc. Rev. 2018, 47, 9046-9068.

5. Kulkarni, S.S.; Sayers, J.; Premdjee, B.; Payne, R.J. Rapid and Efficient Protein Synthesis through Expansion of the Native Chemical Ligation Concept. Nat. Rev. Chem. 2018, 2, 0122.

6. Agouridas, V.; El Mahdi, O.; Diemer, V.; Cargoet, M.; Monbaliu, J.-C.M.; Melnyk, O. Native Chemical Ligation and Extended Methods. Mechanisms, Catalysis, Scope and Limitations. Chem. Rev. 2019, 12, 7328-7443.

7. Agouridas, V.; El Mahdi, O.; Cargoët, M.; Melnyk, O. A Statistical View of Protein Chemical Synthesis Using NCL and Extended Methodologies. Bioorg. Med. Chem. 2017, 25, 4938-4945.

8. Dawson, P.E.; Churchill, M.J.; Ghadiri, M.R.; Kent, S.B.H. Modulation of Reactivity in Native Chemical Ligation through the Use of Thiol Additives. J. Am. Chem. Soc. 1997, 119, 4325-4329.

9. Mitchell, N.J.; Malins, L.R.; Liu, X.; Thompson, R.E.; Chan, B.; Radom, L.; Payne, R.J. Rapid Additive-Free SelenocystineSelenoester Peptide Ligation. J. Am. Chem. Soc. 2015, 137, 14011-14014.

10. Chisholm, T.S.; Clayton, D.; Dowman, L.J.; Sayers, J.; Payne, R.J. Native Chemical Ligation-Photodesulfurization in Flow. J. Am. Chem. Soc. 2018, 29, 9020-9024.

11. Ollivier, N.; Toupy, T.; Hartkoorn, R.C.; Desmet, R.; Monbaliu, J.-C.M.; Melnyk, O. Accelerated Microfluidic Native Chemical Ligation at Difficult Amino Acids toward Cyclic Peptides. Nat. Commun. 2018, 9, No 2847.

12. Durek, T.; Alewood, P.F. Preformed Selenoesters Enable Rapid Native Chemical Ligation at Intractable Sites. Angew. Chem. Int. Ed. 2011, 50, 12042-12045.

13. Zheng, J.-S.; Tang, S.; Huang, Y.-C.; Liu, L. Development of New Thioester Equivalents for Protein Chemical Synthesis. Acc. Chem. Res. 2013, 46, 2475-2484.

14. Ollivier, N.; Behr, J.B.; El-Mahdi, O.; Blanpain, A.; Melnyk, O. Fmoc Solid-Phase Synthesis of Peptide Thioesters Using an Intramolecular N,S-Acyl Shift. Org. Lett. 2005, 7, 2647-2650.

15. Ohta, Y.; Itoh, S.; Shigenaga, A.; Shintaku, S.; Fujii, N.; Otaka, A. Cysteine-Derived S-Protected Oxazolidinones: Potential Chemical Devices for the Preparation of Peptide Thioesters. Org. Lett. 2006, 8, 467-470.

16. Kawakami, T.; Aimoto, S. The Use of a Cysteinyl Prolyl Ester (CPE) Autoactivating Unit in Peptide Ligation Reactions. Tetrahedron 2009, 65, 3871-3877 
17. Kang, J.; Richardson, J.P.; Macmillan, D. 3-Mercaptopropionic Acid-Mediated Synthesis of Peptide and Protein Thioesters. Chem. Commun. 2009, 407-409.

18. Ollivier, N.; Dheur, J.; Mhidia, R.; Blanpain, A.; Melnyk, O. Bis(2-Sulfanylethyl)Amino Native Peptide Ligation. Org. Lett. 2010, 12, 5238-5241.

19. Macmillan, D.; De Cecco, M.; Reynolds, N.L.; Santos, L.F.A.; Barran, P.E.; Dorin, J.R. Synthesis of Cyclic Peptides through an Intramolecular Amide Bond Rearrangement. ChemBioChem 2011, 12, 2133-2136.

20. Hou, W.; Zhang, X.; Li, F.; Liu, C.F. Peptidyl N,N-Bis(2-Mercaptoethyl)-Amides as Thioester Precursors for Native Chemical Ligation. Org. Lett. 2011, 13, 386-389.

21. Sato, K.; Shigenaga, A.; Tsuji, K.; Tsuda, S.; Sumikawa, Y.; Sakamoto, K.; Otaka, A. N-sulfanylethylanilide Peptide as a Crypto-Thioester Peptide. ChemBioChem 2011, 12, 1840-1844.

22. Adams, A.L.; Macmillan, D. Investigation of Peptide Thioester Formation via N->Se Acyl Transfer. J. Pept. Sci. 2013, 19, 6573.

23. Taichi, M.; Hemu, X.; Qiu, Y.; Tam, J.P. A Thioethylalkylamido (TEA) Thioester Surrogate in the Synthesis of a Cyclic Peptide via a Tandem Acyl Shift. Org. Lett. 2013, 15, 2620-2623.

24. Ruff, Y.; Garavini, V.; Giuseppone, N. Reversible Native Chemical Ligation: A Facile Access to Dynamic Covalent Peptides. J. Am. Chem. Soc. 2014, 136, 6333-6339.

25. Burlina, F.; Papageorgiou, G.; Morris, C.; White, P.D.; Offer, J. In Situ Thioester Formation for Protein Ligation Using $\alpha-$ Methylcysteine. Chem. Sci. 2014, 5, 766-770.

26. Asahina, Y.; Nabeshima, K.; Hojo, H. Peptidyl N-Alkylcysteine as a Peptide Thioester Surrogate in the Native Chemical Ligation. Tetrahedron Lett. 2015, 56, 1370-1373.

27. Eto, M.; Naruse, N.; Morimoto, K.; Yamaoka, K.; Sato, K.; Tsuji, K.; Inokuma, T.; Shigenaga, A.; Otaka, A. Development of an Anilide-Type Scaffold for the Thioester Precursor N-Sulfanylethylcoumarinyl Amide. Org. Lett. 2016, 18, 4416-4419.

28. Terrier, V.P.; Adihou, H.; Arnould, M.; Delmas, A.F.; Aucagne, V. A Straightforward Method for Automated Fmoc-Based Synthesis of Bio-Inspired Peptide Crypto-Thioesters. Chem. Sci. 2016, 7, 339-345.

29. Tsuda, S.; Mochizuki, M.; Sakamoto, K.; Denda, M.; Nishio, H.; Otaka, A.; Yoshiya, T. N-Sulfanylethylaminooxybutyramide (SEAoxy): A Crypto-Thioester Compatible with Fmoc Solid-Phase Peptide Synthesis. Org. Lett. 2016, 18, $5940-5943$.

30. Rao, C.; Liu, C.F. Peptide Weinreb Amide Derivatives as Thioester Precursors for Native Chemical Ligation. Org. Biomol. Chem. 2017, 15, 2491-2496.

31. Shelton, P.M.; Weller, C.E.; Chatterjee, C. A Facile N-Mercaptoethoxyglycinamide (MEGA) Linker Approach to Peptide Thioesterification and Cyclization. J. Am. Chem. Soc. 2017, 139, 3946-3949.

32. Ollivier, N.; Desmet, R.; Drobecq, H.; Blanpain, A.; Boll, E.; Leclercq, B.; Mougel, A.; Vicogne, J.; Melnyk, O. A Simple and Traceless Solid Phase Method Simplifies the Assembly of Large Peptides and the Access to Challenging Proteins. Chem. Sci. 2017, 8, 5362-5370

33. Raibaut, L.; Cargoët, M.; Ollivier, N.; Chang, Y.M.; Drobecq, H.; Boll, E.; Desmet, R.; Monbaliu, J.-C.M.; Melnyk, O. Accelerating Chemoselective Peptide Bond Formation Using Bis(2-Selenylethyl)Amido Peptide Selenoester Surrogates. Chem. Sci. 2016, 7, 2657-2665

34. Bouchenna, J.; Sénéchal, M.; Drobecq, H.; Vicogne, J.; Melnyk, O. Total Chemical Synthesis of All SUMO-2/3 Dimer Combinations. Bioconjugate Chem. 2019, 30, 2967-2973.

35. Abboud, S.A.; Cisse, E.h.; Doudeau, M.; Bénédetti, H.; Aucagne, V. A Straightforward Methodology to Overcome Solubility Challenges for N-Terminal Cysteinyl Peptide Segments Used in Native Chemical Ligation. Chem. Sci. 2021.

36. Nakamura, T.; Sato, K.; Naruse, N.; Kitakaze, K.; Inokuma, T.; Hirokawa, T.; Shigenaga, A.; Itoh, K.; Otaka, A. Tailored Synthesis of 162-Residue S-Monoglycosylated GM2-Activator Protein (Gm2ap) Analogues That Allows Facile Access to a Protein Library. Chembiochem 2016, 17, 1986-1992. 
37. Sato, K.; Shigenaga, A.; Kitakaze, K.; Sakamoto, K.; Tsuji, D.; Itoh, K.; Otaka, A. Chemical Synthesis of Biologically Active Monoglycosylated GM2-Activator Protein Analogue Using N-sulfanylethylanilide Peptide. Angew. Chem. Int. Ed. 2013, $52,7855-7859$.

38. Sun, H.; Brik, A. The Journey for the Total Chemical Synthesis of a 53 Kda Protein. Acc. Chem. Res. 2019, 52, 3361-3371.

39. Kumar, K.S.; Bavikar, S.N.; Spasser, L.; Moyal, T.; Ohayon, S.; Brik, A. Total Chemical Synthesis of a 304 Amino Acid K48Linked Tetraubiquitin Protein. Angew. Chem. Int. Ed. 2011, 50, 6137-6141.

40. Pira, S.L.; El Mahdi, O.; Raibaut, L.; Drobecq, H.; Dheur, J.; Boll, E.; Melnyk, O. Insight into the SEA Amide Thioester Equilibrium. Application to the Synthesis of Thioesters at Neutral pH. Org. Biomol. Chem. 2016, 14, 7211-7216.

41. Hupe, D.J.; Jencks, W.P. Nonlinear Structure-Reactivity Correlations. Acyl Transfer between Sulfur and Oxygen Nucleophiles. J. Am. Chem. Soc. 1977, 99, 451-464.

42. Cargoët, M.; Diemer, V.; Snella, B.; Desmet, R.; Blanpain, A.; Drobecq, H.; Agouridas, V.; Melnyk, O. Catalysis of ThiolThioester Exchange by Water-Soluble Alkyldiselenols Applied to the Synthesis of Peptide Thioesters and SEAMediated Ligation. J. Org. Chem. 2018, 83, 12584-12594.

43. Shefter, E.; Kennard, O. Crystal and Molecular Structure of Acetylselenocholine Iodide. Science 1966, $153,1389$.

44. Chu, S.-H.; Mautner, H.G. Analogs of Neuroeffectors. V. Neighboring-Group Effects in the Reactions of Esters, Thiolesters, and Selenolesters. The Hydrolysis and Aminolysis of Benzoylcholine, Benzoylthiolcholine, Benzoylselenolcholine, and of their Dimethylamino Analogs. J. Org. Chem. 1966, 31, 308-312.

45. Günther, W.H.H.; Mautner, H.G. Analogs of Parasympathetic Neuroeffectors. I. Acetylselenocholine, Selenocholine, and Related Compounds1. J. Med. Chem. 1964, 7, 229-232.

46. Krensky, A.M.; Clayberger, C. Biology and Clinical Relevance of Granulysin. Tissue antigens 2009, 73, 193-198.

47. Stenger, S.; Hanson, D.A.; Teitelbaum, R.; Dewan, P.; Niazi, K.R.; Froelich, C.J.; Ganz, T.; Thoma-Uszynski, S.; Melian, A.; Bogdan, C. et al. An Antimicrobial Activity of Cytolytic T Cells Mediated by Granulysin. Science 1998, 282, $121-125$.

48. Pena, S.V.; Hanson, D.A.; Carr, B.A.; Goralski, T.J.; Krensky, A.M. Processing, Subcellular Localization, and Function of 519 (Granulysin), a Human Late T Cell Activation Molecule with Homology to Small, Lytic, Granule Proteins. J. Immunol. $1997,158,2680-2688$.

49. Krief, A.; Dumont, W.; Delmotte, C. Reaction of Organic Selenocyanates with Hydroxides: The One-Pot Synthesis of Dialkyl Diselenides from Alkyl Bromides. Angew. Chem. Int. Ed. 2000, 39, 1669-1672.

50. Pena, S.V.; Krensky, A.M. Granulysin, a New Human Cytolytic Granule-Associated Protein with Possible Involvement in Cell-Mediated Cytotoxicity. Semin. Immunol. 1997, 9, 117-125.

51. Deng, A.; Chen, S.; Li, Q.; Lyu, S.C.; Clayberger, C.; Krensky, A.M. Granulysin, a Cytolytic Molecule, Is Also a Chemoattractant and Proinflammatory Activator. J. Immunol. 2005, 174, 5243-5248.

52. Boll, E.; Ebran, J.P.; Drobecq, H.; El-Mahdi, O.; Raibaut, L.; Ollivier, N.; Melnyk, O. Access to Large Cyclic Peptides by a OnePot Two-Peptide Segment Ligation/Cyclization Process. Org. Lett. 2015, 17, 130-133.

53. Haack, T.; Mutter, M. Serine Derived Oxazolidines as Secondary Structure Disrupting, Solubilizing Building Blocks in Peptide Synthesis. Tetrahedron Lett. 1992, 33, 1589-1592.

54. Anderson, D.H.; Sawaya, M.R.; Cascio, D.; Ernst, W.; Modlin, R.; Krensky, A.; Eisenberg, D. Granulysin Crystal Structure and a Structure-Derived Lytic Mechanism. J. Mol. Biol. 2003, 325, 355-365.

55. Pichavant, M.; Taront, S.; Jeannin, P.; Breuilh, L.; Charbonnier, A.S.; Spriet, C.; Fourneau, C.; Corvaia, N.; Heliot, L.; Brichet, A. et al. Impact of Bronchial Epithelium on Dendritic Cell Migration and Function: Modulation by the Bacterial Motif KpOmpA. J. Immunol. 2006, 177, 5912-5919. 